\title{
Properties and Application of a Partially Purified Thermoalkali Stable Xylanase from Cellulosimicrobium sp. MTCC 10645 in Kraft Pulp Bleaching
}

\author{
Rajashri D. Kamble, ${ }^{1}$ and Anandrao R. Jadhav ${ }^{2}$ \\ ${ }^{1}$ Department of Biotechnology Engineering, Tatyasaheb Kore Institute of Engineering and Technology, Warananagar, \\ Kolhapur, Maharashtra 416113, India \\ ${ }^{2}$ Department of Microbiology, KRP Kanya Mahavidyalaya, Islampur, Sangli, Maharashtra 415414, India
}

Correspondence should be addressed to Rajashri D. Kamble; rajashri.kamble@gmail.com

Received 25 April 2012; Accepted 23 May 2012

Academic Editors: W. A. Kues and O. V. Singh

Copyright (C) 2013 R. D. Kamble and A. R. Jadhav. This is an open access article distributed under the Creative Commons Attribution License, which permits unrestricted use, distribution, and reproduction in any medium, provided the original work is properly cited.

\begin{abstract}
The most promising application of xylanases (E.C. 3.2.1.8) is in the prebleaching of kraft pulp. The present paper reports bleaching effects of a thermoalkali stable xylanase from Cellulosimicrobium sp. MTCC 10645. The bacterium produced thermo-alkali stable xylanase in a basal medium supplemented with wheat bran $(1 \% \mathrm{w} / \mathrm{v})$, which was optimally active at $\mathrm{pH} 7.0$ and $50^{\circ} \mathrm{C}$. The xylanase was stable at temperature $50^{\circ} \mathrm{C}$ for $1 \mathrm{~h}$ and retained up to $86 \%$ of the activity. The xylanase was stable in a broad $\mathrm{pH}$ range of $6.0-11.0$ for $1 \mathrm{~h}$ at $50^{\circ} \mathrm{C}$. Metal ions $\mathrm{Ca}^{+2}, \mathrm{Hg}^{+2}$, and $\mathrm{Pb}^{+2}$ were inhibitory for xylanase retaining $72.3 \%, 35.07 \%$ and $36.7 \%$ relative activity at $10 \mathrm{mM}$ concentration, whereas $\mathrm{Fe}^{+2}, \mathrm{Cu}^{+2}, \mathrm{Mn}^{+2}, \mathrm{Na}^{+2}, \mathrm{Co}^{+2}$, and $\mathrm{Zn}^{+2}$ were inducers at concentrations of $5 \mathrm{mM}$ and $10 \mathrm{mM}$. The enzyme exhibited greater binding affinity exclusively for xylans but not for avicel, CMC, cellobiose, starch, or p-nitrophenyl xylopyranoside. Parachloromercuric benzoate and iodoacetamide were found stimulatory, while potassium permanganate, cysteine, and cystine markedly reduced the activity. The xylanase dose of $2.0 \mathrm{U} / \mathrm{g}$ dry weight pulp of $10 \%$ consistency gave optimum bleach boosting of kraft pulp at $\mathrm{pH} 8.0$ and temperature $50^{\circ} \mathrm{C}$ for $5 \mathrm{~h}$ reaction time.
\end{abstract}

\section{Introduction}

The most promising application of xylanases (E.C. 3.2.1.8) is in the prebleaching of kraft pulp. The pulp and paper industry is modifying its pulping, bleaching, and effluent treatment technologies to reduce the environmental impact of mill effluents. Prebleaching of kraft pulps with xylanases lowers chlorine charges, which reduce chloroorganic discharges [1-3]. Tremblay and Archibald reported the delignification of unbleached softwood and hardwood kraft pulps [4]. Thus reducing the $\mathrm{Cl}_{2}$ required to achieve a given degree of bleaching $[3,5-7]$. The public concern on the impact of pollutants from paper and pulp industries, which use chlorine as the bleaching agent act as strong driving force in developing biotechnology aided techniques for novel bleaching that is biobleaching $[8,9]$. The occurrence of cellulase contamination is posing a major threat in applying the xylanases in biobleaching. The cellulases easily result in the hydrolysis of cellulose, which should be the main recovered product in paper industry. However, the enzyme preparations from microorganisms producing higher levels of xylanases with no cellulase activity can be applied in paper industry because the loss of pulp viscosity is at minimum level [10]. Xylanases have been reported from bacteria, fungi, actinomycetes, and yeasts [11-14]. The use of abundantly available and cost-effective agricultural residues to achieve higher xylanase yields and simple and rapid purification procedures provide suitable means to reduce the manufacturing cost of biobleached paper. The present paper reports partial purification, properties, and the bleaching effects of an thermo-alkali stable xylanase from Cellulosimicrobium sp. MTCC 10645. 


\section{Materials and Methods}

2.1. Microorganism and Culture Conditions. Cellulosimicrobium sp. MTCC 10645 was isolated from the compost sample collected at Kolhapur (M.S., India). The culture was purified and maintained on xylan agar ( $\mathrm{pH}$ 7.0) supplemented with $0.1 \%$ oat spelt xylan. The xylanase production was carried out in $250 \mathrm{~mL}$ Erlenmeyer flasks, each containing $18 \mathrm{~mL}$ basal salt solution supplemented with $10 \mathrm{~g}$ of wheat bran ( $1: 1.8$ moisture ratio) in static conditions [15]. Each flask was inoculated with $2 \%$ bacterial inoculum and incubated at $40^{\circ} \mathrm{C}$ for 7 days.

2.2. Assays. Xylanase activity was determined by measuring the release of reducing sugars from birchwood xylan (1\% w/v) using the dinitrosalicylic acid method [16]. One unit of xylanase activity was defined as the amount of enzyme that liberates $1 \mu \mathrm{mol}$ of reducing sugars equivalent to xylose per minute under the assay conditions $\left(50^{\circ} \mathrm{C}, 50 \mathrm{mM}\right.$ sodium phosphate buffer $\mathrm{pH}$ 7.0). Total soluble protein was measured using bovine serum albumin as a standard [17].

2.3. Partial Purification and Properties of Xylanase. The cell free supernatant $(75 \mathrm{~mL})$ was precipitated using fractional (35-80\%) ammonium sulphate saturation. The precipitate was dialysed and the protein thus obtained was treated as partially purified enzyme and used for further experiments. The thermal stability was determined by incubating the equal volume of enzyme solution at temperatures ranges between $30^{\circ} \mathrm{C}-80^{\circ} \mathrm{C}$ for $4 \mathrm{~h}$. Optimal $\mathrm{pH}$ for xylanase activity was determined using different buffers $50 \mathrm{mM}$ sodium phosphate (pH 6.0, 7.0), $50 \mathrm{mM}$ Tris $\mathrm{HCl}(\mathrm{pH} 8.0,9.0), 50 \mathrm{mM}$ carbonate bicarbonate buffer ( $\mathrm{pH} 10.0$ ) and $50 \mathrm{mM}$ glycineNaOH buffer ( $\mathrm{pH} 11.0)$. The $\mathrm{pH}$ stability was determined by incubating the equal volume of enzyme solution with different buffers ranging from $6.0-11.0$ at $50^{\circ} \mathrm{C}$ and the residual activities were determined after $1 \mathrm{~h}$. The effect of various metal ions solution of chloride salts of either $\mathrm{Ca}^{+2}, \mathrm{Hg}^{+2}, \mathrm{Fe}^{+2}, \mathrm{Cu}^{+2}$, $\mathrm{Mn}^{+2}, \mathrm{Na}^{+2}, \mathrm{Co}^{+2}, \mathrm{~Pb}^{+2}$, and $\mathrm{Zn}^{+2}$ at $1 \mathrm{mM}, 5 \mathrm{mM}$, and $10 \mathrm{mM}$ concentration on enzyme activity was determined by incubating the enzyme with respective compounds at room temperature for $1 \mathrm{~h}$ followed by determination of residual activities under standard assay conditions. Substrate specificity of the xylanase was studied by using $1 \%$ xylan, cellobiose, starch, carboxy methyl cellulose (CMC), $p$ nitrophenyl xylopyranoside, and avicel as substrates. Effect of additives like parachloromercuric benzoate, iodoacetamide, potassium permanganate, cysteine, and cystine $(0.5 \mathrm{mM})$ was tested on xylanase activity.

2.4. Xylanase Bleaching of Kraft Pulp. The enzymatic bleaching studies were performed at $\mathrm{pH} 8.0$ at $50^{\circ} \mathrm{C}$, unless otherwise mentioned. The optimization of enzyme dose, pulp consistency and reaction time was carried out by treating the pulp with different doses of xylanase from Cellulosimicrobium sp. MTCC 10645 at $2 \mathrm{U} / \mathrm{g}, 5 \mathrm{U} / \mathrm{g}, 10 \mathrm{U} / \mathrm{g}$, and $25 \mathrm{U} / \mathrm{g}$ oven dried pulp of consistency $3.0 \%, 5 \%$ and $10 \%$ for variable time intervals $3 \mathrm{~h}$ and $5 \mathrm{~h}$. The chemical characteristics of Kraft pulp: kappa number (T $236 \mathrm{~cm}-85$ ), release of reducing sugars,

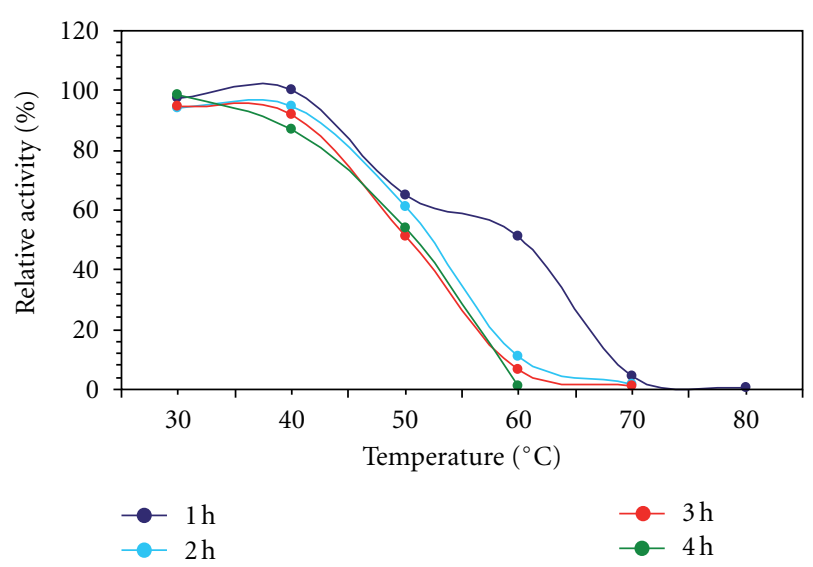

(a)

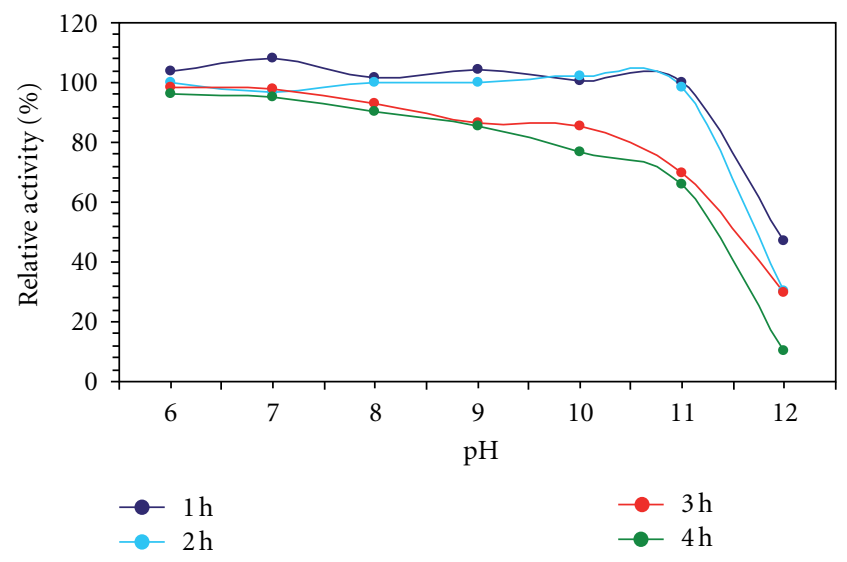

(b)

FIGURE 1: (a) Temperature stability profile of xylanase assayed at $\mathrm{pH}$ 7.0 for $4 \mathrm{~h}$. (b) $\mathrm{pH}$ stability profile of xylanase assayed at $50^{\circ} \mathrm{C}$ for $4 \mathrm{~h}$.

release of phenolic compounds (A237 $\mathrm{nm}$ and $280 \mathrm{~nm}$ ), and hydrophobic compounds (A465 nm) were determined [16, $18,19]$.

\section{Results and Discussion}

3.1. Xylanase Production. The test organism was isolated from compost sample collected at Kolhapur (MS, India). It was identified as Cellulosimicrobium sp. and deposited with Microbial Type Culture Collection no. 10645 at IMTECH, Chandigarh, India. Xylanase production was monitored in Cellulosimicrobium sp. MTCC 10645 grown for 7 days in static conditions on wheat bran. Xylanase activity appeared after day 1 and reached maximum $(960 \mathrm{U} / \mathrm{mL})$ after day 2 at $\mathrm{pH} 7.0$ and $40^{\circ} \mathrm{C}$.

3.2. Properties of Partially Purified Xylanase. The extracellular xylanase from Cellulosimicrobium sp. MTCC 10645 was partially purified at $80 \%\left(\mathrm{NH}_{4}\right)_{2} \mathrm{SO}_{4}$ saturation with a yield of $52.03 \%$ and a purification fold of 16.0 . The partially purified xylanase from Cellulosimicrobium sp. MTCC 10645 was optimally active at $50^{\circ} \mathrm{C}$ and $\mathrm{pH} 7.0$ (Figures 1 (a) and $1(b))$. 
TABle 1: Effect of metal ions ( $1 \mathrm{mM}, 5 \mathrm{mM}$, and $10 \mathrm{mM})$ on xylanase.

\begin{tabular}{lccc}
\hline Metal ions & \multicolumn{3}{c}{$\begin{array}{c}\text { (Relative activity \%) } \\
5 \mathrm{mM}\end{array}$} \\
\hline $\mathrm{Ca}^{+2}$ & 88.8 & 85.2 & $70 \mathrm{mM}$ \\
$\mathrm{Hg}^{+2}$ & 91.97 & 90.8 & 35.3 \\
$\mathrm{Fe}^{+2}$ & 99.93 & 100.09 & 78.09 \\
$\mathrm{Cu}^{+2}$ & 94.02 & 93.23 & 87.6 \\
$\mathrm{Mn}^{+2}$ & 97.98 & 100 & 93.2 \\
$\mathrm{Na}^{+2}$ & 112.8 & 109.8 & 99.8 \\
$\mathrm{Co}^{+2}$ & 100.9 & 102.1 & 83.1 \\
$\mathrm{~Pb}^{+2}$ & 82.9 & 72.3 & 36.7 \\
$\mathrm{Zn}^{+2}$ & 100.9 & 90.96 & 88.11 \\
\hline
\end{tabular}

The xylanase was stable at temperature $50^{\circ} \mathrm{C}$ for $1 \mathrm{~h}$ and retained up to $86 \%$ of the activity. Interestingly at $50^{\circ} \mathrm{C}$ relative activity was comparatively constant up to $4 \mathrm{~h}$ of incubation at $\mathrm{pH}$ 7.0. Reportedly, bacterial xylanases found more thermostable than fungal xylanases. Most of the thermostable xylanases are produced by mesophilic bacteria $[15,20]$. Two xylanases which gave the highest activity at $50^{\circ} \mathrm{C}$ were purified cell-free extract of Cephalosporium sp. [21]. The xylanase obtained from Cellulosimicrobium sp. MTCC 10645 was stable in a broad $\mathrm{pH}$ range of $6.0-11.0$ for $1 \mathrm{~h}$ at $50^{\circ} \mathrm{C}$. It showed highest activity at $\mathrm{pH} 7.0$ and found more stable at $\mathrm{pH} 7.0$ even after $4 \mathrm{~h}$ of incubation. The most desirable characteristic was its steady stability at alkaline $\mathrm{pH}$ values. Mathrani and Ahring isolated a thermophilic and alkaliphilic xylanase from Dictyoglomus isolate and reported that almost $100 \%$ activity shown by the xylanase at pH 5.5 to 9.0 [22].

As shown in Table 1 , metal ions $\mathrm{Ca}^{+2}, \mathrm{Hg}^{+2}$, and $\mathrm{Pb}^{+2}$ were inhibitory for Cellulosimicrobium sp., MTCC 10645 xylanase retaining $72.3 \%, 35.07 \%$, and $36.7 \%$ relative activity at $10 \mathrm{mM}$ concentration, while $\mathrm{Fe}^{+2}, \mathrm{Cu}^{+2}, \mathrm{Mn}^{+2}, \mathrm{Na}^{+2}, \mathrm{Co}^{+2}$, and $\mathrm{Zn}^{+2}$ were inducers at concentrations $5 \mathrm{mM}$ and $10 \mathrm{mM}$. Sreenath and Joseph reported the stimulatory effect of $\mathrm{Ca}^{+2}$ and $\mathrm{Na}^{+2}$ on xylanases of Streptomyces exfoliates [23]. Gessesse reported the inhibitory activity of $\mathrm{Pb}^{+2}$ on xylanase at $1 \mathrm{mM}$ concentration in an alkaliphilic Bacillus sp. with $8 \%$ residual activity [24].

The xylanase was active on oat spelt and birchwood xylans but not on avicel, CMC, cellobiose, starch, or $p$-nitrophenyl xylopyranoside. Purified xylanase was not active on avicel, CMC, cellobiose, starch, and $p$-nitrophenyl xylopyranoside even when the enzyme concentration was 5 times greater than used in normal assay at an incubation period of 20 minutes rather than 5 minutes suggesting that enzyme is a true xylanase. Similarly, xylanase with absolute substrate specificity was purified from Trichoderma viride [25]. Two endo-1,4- $\beta$-xylanases from Irpex lacteus (Polyporus tulipiferae) were purified, named xyl I and III which did not showed activity towards glycans such as starch, pachyman, and avicel (microcrystalline cellulose) but showed one twentieth activity towards carboxymethyl cellulose [26]. Additives parachloromercuric benzoate and iodoacetamide were found stimulatory, while potassium permanganate, cysteine,

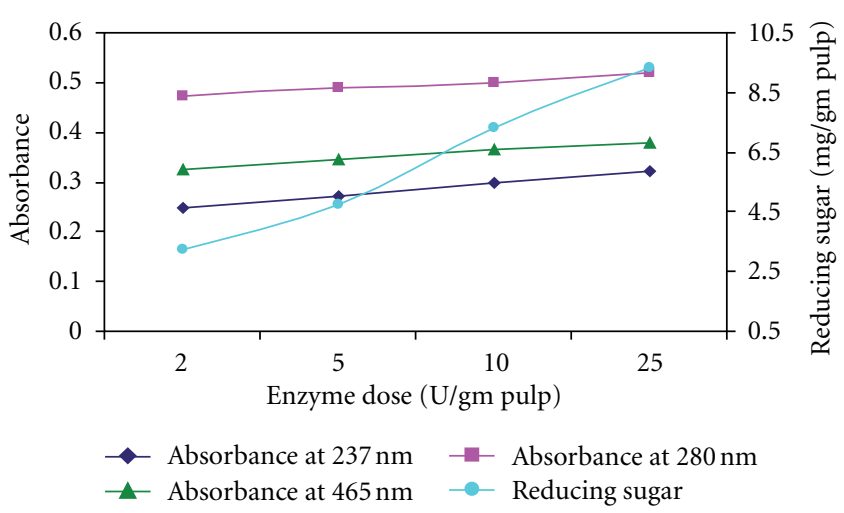

FIGURE 2: Optimization of xylanase dose for the enzymatic bleaching of kraft pulp at $50^{\circ} \mathrm{C}, \mathrm{pH} 8.0$ after $5 \mathrm{~h}$.

and cystine markedly reduced the enzyme activity. Similar observation was reported by Anthony et al. in case of highmolecular-weight cellulase free xylanase from alkali tolerant Aspergillus fumigatus AR1 [27]. Iodoacetamide was found to be stimulatory for xylanase activity at $0.5 \mathrm{mM}$ and $1.0 \mathrm{mM}$ concentrations. These compounds showed similar effect on xylanase isolated from Thermomonospora sp. [28].

3.3. Biobleaching of Kraft Pulp. The xylanase dose for biobleaching of kraft pulp at $50^{\circ} \mathrm{C}$ was optimized as $2.0 \mathrm{U} / \mathrm{g}$ of moisture free pulp (Figure 2). Reducing sugars released were $3.235 \mathrm{mg} / \mathrm{g}, 4.75 \mathrm{mg} / \mathrm{g}, 7.34 \mathrm{mg} / \mathrm{g}$, and $9.321 \mathrm{mg} / \mathrm{g}$ of the pulp, when the enzyme dose given $2 \mathrm{U} / \mathrm{g}, 5 \mathrm{U} / \mathrm{g}, 10 \mathrm{U} / \mathrm{g}$, and $25 \mathrm{U} / \mathrm{g}$, respectively. At wavelengths $237 \mathrm{~nm}, 280 \mathrm{~nm}$, and $465 \mathrm{~nm}$, the absorbance was found to be increased from 0.247 to $0.321,0.471$ to 0.521 , and 0.325 to 0.378 with increased dose of enzyme, respectively. $\mathrm{Li}$ et al. reported that the amount of reducing sugars released from wheat straw pulp by the xylanase isolated from Thermomyces lanuginosus CBS 288.54 was significantly greater with increasing time [29].

When kraft pulp was treated with xylanase from Cellulosimicrobium sp. MTCC 10645, the release of light absorbing material and reducing sugars increased with increase in consistency. Release of absorbing materials at $237 \mathrm{~nm}$, $280 \mathrm{~nm}$, and $465 \mathrm{~nm}$ can be correlated with release of lignin. The absorbance measured was highest at $280 \mathrm{~nm}$ wavelength as compared to $237 \mathrm{~nm}$ and $465 \mathrm{~nm}$ at $10 \%$ pulp consistency. At $237 \mathrm{~nm}$ wavelength, the absorbance measured was $0.215,0.231$, and 0.256 at $3 \%, 5 \%$, and $10 \%$ consistency of pulp, respectively. At $0 \%$ pulp consistency, the absorbance measured was 0.211 at $237 \mathrm{~nm}$ wavelength. At $465 \mathrm{~nm}$ the absorbance measured was comparatively less 0.218 at $10 \%$ pulp consistency. The reducing sugars released were $0.75 \mathrm{mg} / \mathrm{g}, 1.15 \mathrm{mg} / \mathrm{g}, 1.65 \mathrm{mg} / \mathrm{g}$, and $2.161 \mathrm{mg} / \mathrm{g}$ of pulp at $0 \%, 3 \%, 5 \%$, and $10 \%$ consistency, respectively (Figure 3 ). Elegir et al. reported that the release of chromophores correlates well with total sugar release and this can be considered as a simple method to determine the efficacy of the enzyme treatment [30]. Suurnakki et al. reported that the decrease in the lignin content of the pulp did correlate with the degree of solubilization of carbohydrates [31]. In 


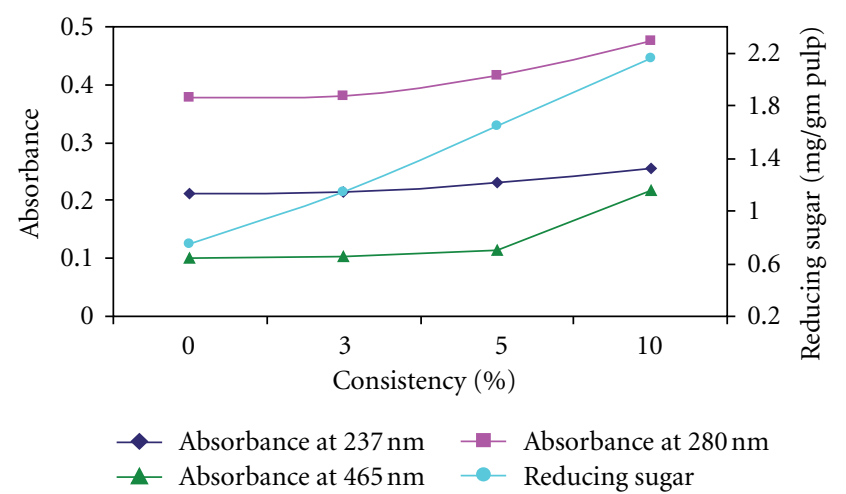

FIGURE 3: Optimization of consistency of pulp for the enzymatic bleaching of kraft pulp at $50^{\circ} \mathrm{C}, \mathrm{pH} 8.0$ after $5 \mathrm{~h}$.

the xylanase treatment, pulp xylan was hydrolysed to soluble xylooligomers. The increase in absorbance at $280 \mathrm{~nm}$ as well as the increase in the liberation of reducing sugars indicated the effective action of xylanase on pulp.

In the present study, the brightness increased from $30.13 \%$ (brightness of unbleached pulp) to $70.45 \%$ after the treatment of the kraft pulp with xylanase $25 \mathrm{U} / \mathrm{g}$ of pulp with a retention time of $5 \mathrm{~h}$ at $10 \%$ consistency. The kappa number was reduced from 14.90 (kappa number of unbleached pulp) to 1.62. Li et al. reported that when wheat straw pulp was treated with the xylanase isolated from Thermomyces lanuginosus CBS 288.54, brightness was improved by $3.93 \%$ ISO [29]. Madlala et al. studied the effect of two xylanases (xylanase P and crude xylanase from Thermomyces lanuginosus) in the bleaching of kraft pulp and found that, xylanase $\mathrm{P}$ (at an enzyme dose $5 \mathrm{U} / \mathrm{g}$ pulp) increased the brightness of kraft pulp by $5.1 \%$ while xylanase from Thermomyces lanuginosus (at an enzyme dose $5 \mathrm{U} / \mathrm{g}$ pulp) increased 2.1\% [8]. Kulkarni and Rao reported an increase in brightness of $2.5 \%$ and $21 \%$ reduction in kappa number by a xylanase (at an enzyme dose $10 \mathrm{U} / \mathrm{g}$ pulp) from Bacillus sp. NCIM 59 on unbleached bagasse pulp [2]. Angayarkanni et al. reported that xylanases from three fungi Aspergillus indicus, Aspergillus flavus, and Aspergillus niveus increased brightness of 42.0-45.0 ISO units from 19.83 ISO units and reduced kappa number of 5.0-6.8 from 18.60 of the kraft pulp [32].

To the best of our knowledge, this is the first paper on the thermo-alkali stable xylanase production from Cellulosimicrobium sp. MTCC 10645.

\section{Acknowledgment}

The authors would like to thank the Director of Warana for paper and pulp industry, Warananagar (MS, India) for providing technical and financial support.

\section{References}

[1] R. Koponer, "Enzyme systems prove their potential," Pulp and Paper International, vol. 33, no. 11, pp. 20-25, 1991.
[2] N. Kulkarni and M. Rao, "Application of xylanase from alkaliphilic thermophilic Bacillus sp. NCIM 59 in biobleaching of bagasse pulp," Journal of Biotechnology, vol. 51, no. 2, pp. 167-173, 1996.

[3] L. Viikari, A. Kantelinen, J. Sundquist, and M. Linko, "Xylanases in bleaching: from an idea to the industry," FEMS Microbiology Reviews, vol. 13, no. 2-3, pp. 335-350, 1994.

[4] L. Tremblay and F. Archibald, "Production of a cloned xylanase in Bacillus cereus and its performance in kraft pulp prebleaching," Canadian Journal of Microbiology, vol. 39, no. 9, pp. 853-860, 1993.

[5] L. Viikari, M. Ranua, A. Kantelinen, J. Sundiquist, and M. Linko, "Bleaching with enzymes," in Biotechnology in the Pulp and Paper Industry: The Third International Conference, $\mathrm{p}$. 67, Swedish Forest Products Research Laboratory, Stockholm, Sweden, 1986.

[6] A. Gessesse and G. Mamo, "Purification and characterization of an alkaline xylanase from alkaliphilic Micrococcus sp. AR-135," Journal of Industrial Microbiology and Biotechnology, vol. 20, no. 3-4, pp. 210-214, 1998.

[7] M. L. Niku-Paavola, M. Ranua, A. Suurnakki, and A. Kantelinen, "Effects of lignin-modifying enzymes on pine kraft pulp," Bioresource Technology, vol. 50, no. 1, pp. 73-77, 1994.

[8] A. M. Madlala, S. Bissoon, S. Singh, and L. Christov, "Xylanaseinduced reduction of chlorine dioxide consumption during elemental chlorine-free bleaching of different pulp types," Biotechnology Letters, vol. 23, no. 5, pp. 345-351, 2001.

[9] P. Bajpai, "Application of enzymes in the pulp and paper industry," Biotechnology Progress, vol. 15, no. 2, pp. 147-157, 1999.

[10] P. Bajpai and P. K. Bajpai, "Development of a process for the production of dissolving kraft pulp using xylanase enzyme," Appita Journal, vol. 54, no. 4, pp. 381-384, 2001.

[11] K. K. Y. Wong, L. U. L. Tan, and J. N. Saddler, "Multiplicity of beta-1,4-xylanase in microorganisms: functions and applications," Microbiological Reviews, vol. 52, no. 3, pp. 305-317, 1988.

[12] R. C. Kuhad and A. Singh, "Lignocellulose biotechnology: current and future prospects," Critical Reviews in Biotechnology, vol. 13, no. 2, pp. 151-172, 1993.

[13] R. C. Kuhad, A. Singh, and K. E. L. Eriksson, "Microorganisms and enzymes involved in the degradation of plant fiber cell walls," Advances in Biochemical Engineering/Biotechnology, vol. 57, pp. 45-125, 1997.

[14] Q. K. Beg, M. Kapoor, L. Mahajan, and G. S. Hoondal, "Microbial xylanases and their industrial applications: a review," Applied Microbiology and Biotechnology, vol. 56, no. 3-4, pp. 326-338, 2001.

[15] R. D. S. Khandeparkar and N. B. Bhosle, "Isolation, purification and characterization of the xylanase produced by Arthrobacter sp. MTCC 5214 when grown in solid-state fermentation," Enzyme and Microbial Technology, vol. 39, no. 4, pp. 732-742, 2006.

[16] G. L. Miller, "Use of dinitrosalicylic acid reagent for determination of reducing sugar," Analytical Chemistry, vol. 31, no. 3, pp. 426-428, 1959.

[17] O. H. Lowry, N. J. Rosebrough, A. L. Farr, and R. J. Randall, "Protein measurement with the Folin phenol reagent," The Journal of biological chemistry, vol. 193, no. 1, pp. 265-275, 1951.

[18] Anon, TAPPI Test Methods, TAPPI, Atlanta, Ga, USA, 1996. 
[19] N. Gupta, V. S. Reddy, S. Maiti, and A. Ghosh, "Cloning, expression, and sequence analysis of the gene encoding the alkali-stable, thermostable endoxylanase from alkalophilic, mesophilic Bacillus sp. strain NG-27," Applied and Environmental Microbiology, vol. 66, no. 6, pp. 2631-2635, 2000.

[20] U. Gupta and R. Kar, "Optimization and scale up of cellulase free endo xylanase production by solid state fermentation on corn cob and by immobilized cells of a thermotolerant bacterial isolate," Jordan Journal of Biological Sciences, vol. 1, pp. 129-134, 2008.

[21] M. K. Kang, P. J. Maeng, and Y. H. Rhee, "Purification and characterization of two xylanases from alkalophilic Cephalosporium sp. strain RYM-202," Applied and Environmental Microbiology, vol. 62, no. 9, pp. 3480-3482, 1996.

[22] I. M. Mathrani and B. K. Ahring, "Thermophilic and alkalophilic xylanases from several Dictyoglomus isolates," Applied Microbiology and Biotechnology, vol. 38, no. 1, pp. 23-27, 1992.

[23] H. K. Sreenath and R. Joseph, "Purification and properties of extracellular xylan hydrolases of Streptomyces exfoliatus," Folia Microbiologica, vol. 27, no. 2, pp. 107-115, 1982.

[24] A. Gessesse, "Purification and properties of two thermostable alkaline xylanases from an alkaliphilic Bacillus sp.," Applied and Environmental Microbiology, vol. 64, no. 9, pp. 3533-3535, 1998.

[25] M. Ujiie, C. Roy, and M. Yaguchi, "Low-molecular-weight xylanase from Trichoderma viride," Applied and Environmental Microbiology, vol. 57, no. 6, pp. 1860-1862, 1991.

[26] T. Kanda, Y. Amano, and K. Nisizawa, "Purification and properties of two endo-1,4- $\beta$-xylanases from Irpex lacteus (Polyporus tulipiferae)," Journal of Biochemistry, vol. 98, no. 6, pp. 1545-1554, 1985.

[27] T. Anthony, K. C. Raj, A. Rajendran, and P. Gunasekaran, "High molecular weight cellulase-free xylanase from alkali-tolerant Aspergillus fumigatus AR1," Enzyme and Microbial Technology, vol. 32, no. 6, pp. 647-654, 2003.

[28] S. P. George, A. Ahmad, and M. B. Rao, "A novel thermostable xylanase from Thermomonospora sp.: influence of additives on thermostability," Bioresource Technology, vol. 78, no. 3, pp. 221-224, 2001.

[29] X. T. Li, Z. Q. Jiang, L. T. Li et al., "Characterization of a cellulase-free, neutral xylanase from Thermomyces lanuginosus CBS 288.54 and its biobleaching effect on wheat straw pulp," Bioresource Technology, vol. 96, no. 12, pp. 1370-1379, 2005.

[30] G. Elegir, M. Sykes, and T. W. Jeffries, "Differential and synergistic action of Streptomyces endoxylanases in prebleaching of kraft pulps," Enzyme and Microbial Technology, vol. 17, no. 10, pp. 954-959, 1995.

[31] A. Suurnakki, A. Kantelinen, J. Buchet, and L. Vikari, "Enzyme aided bleaching of industrial softwood kraft pulps," TAPPI Journal, vol. 77, pp. 111-116, 1994.

[32] J. Angayarkanni, M. Palaniswamy, B. V. Pradeep, and K. Swaminathan, "Biochemical substitution of fungal xylanases for prebleaching of hardwood kraft pulp," African Journal of Biotechnology, vol. 5, no. 10, pp. 921-929, 2006. 

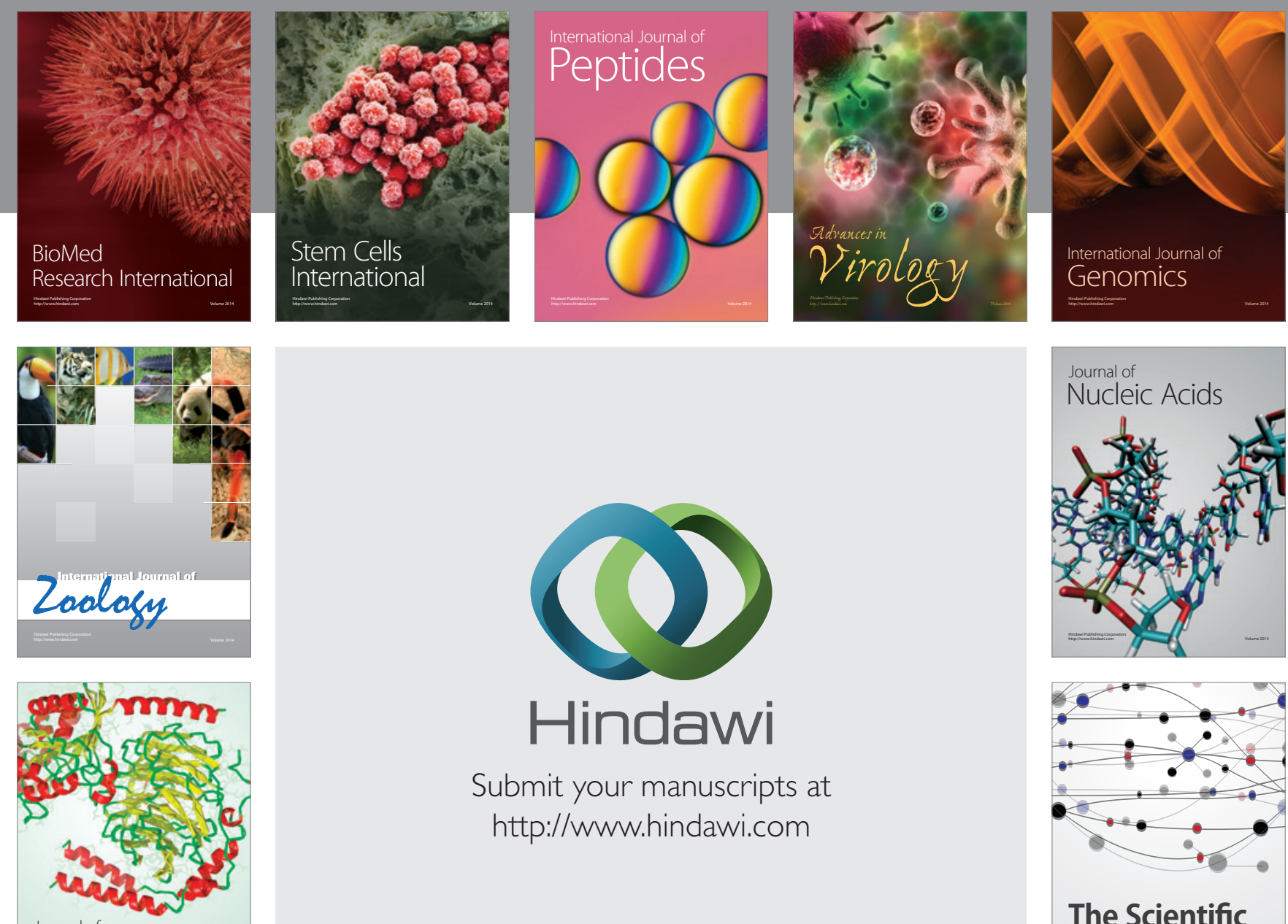

Submit your manuscripts at

http://www.hindawi.com

Journal of
Signal Transduction
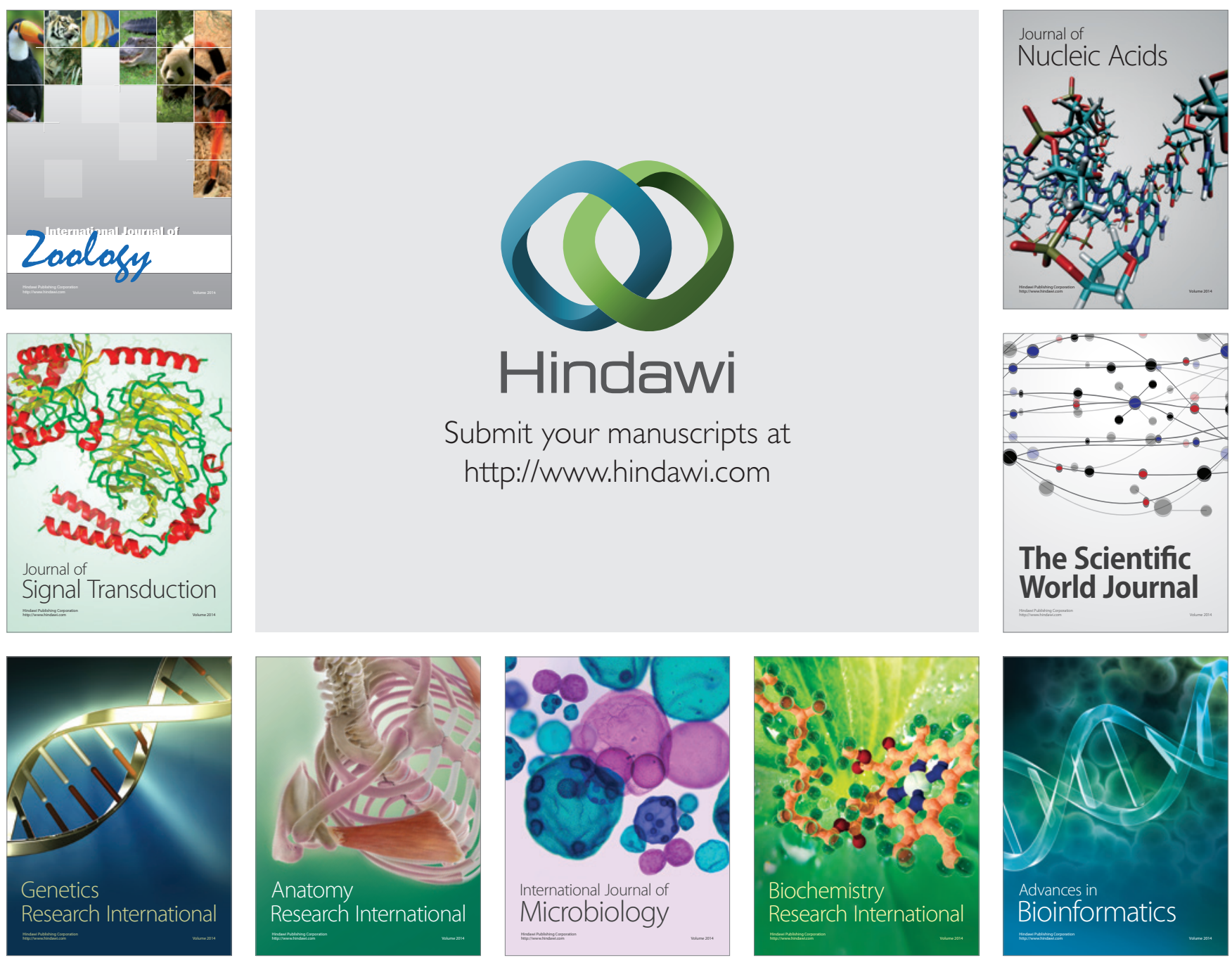

The Scientific World Journal
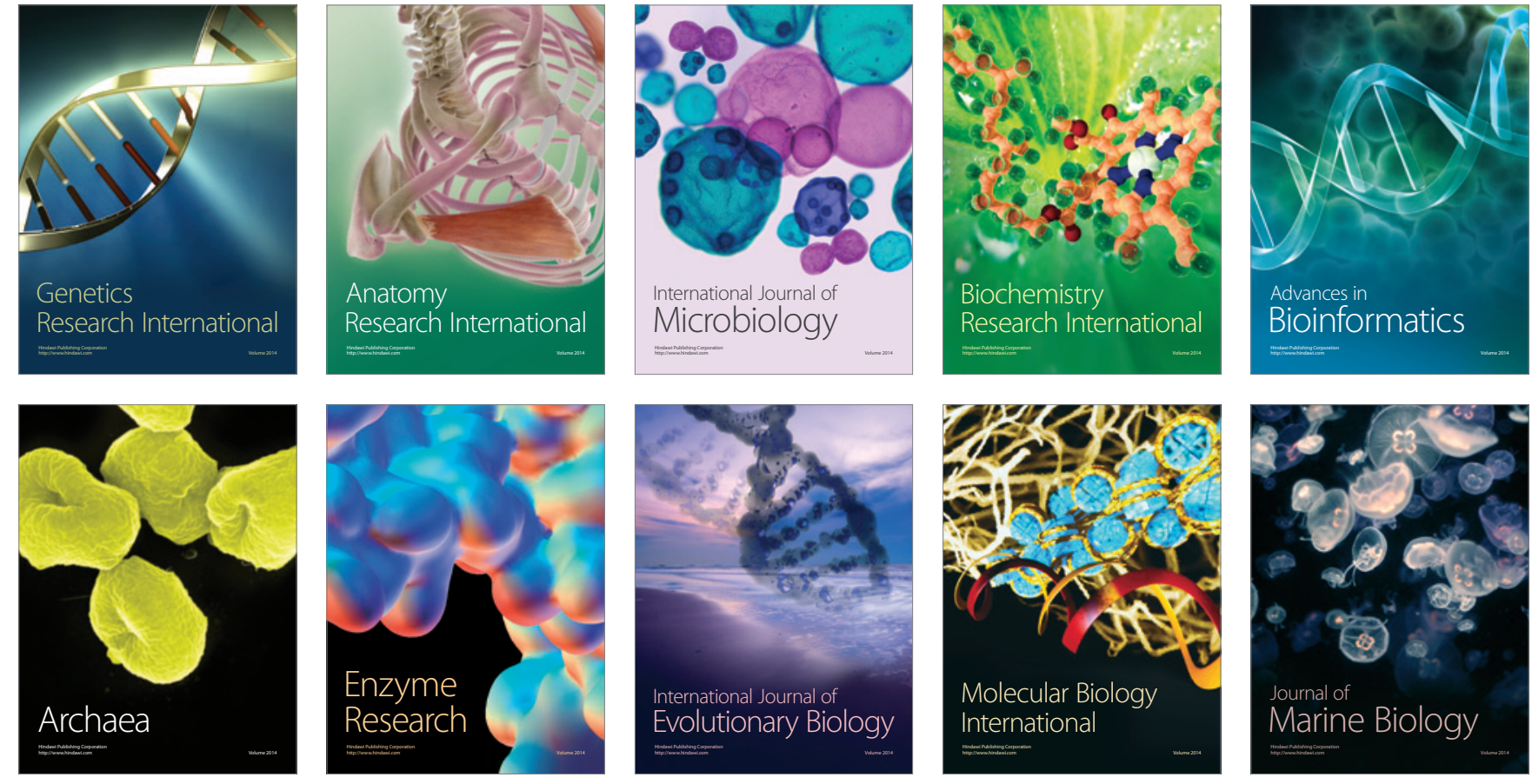